\title{
The Immorality of Requesting Expedited Review
}

Joseph Scott Miller ${ }^{\dagger}$

You write a cover letter to accompany an article you are submitting to multiple law reviews. Like nearly all such letters, it ends with an anodyne expression, such as, "I hope you will accept the piece for publication." It is optimistic, and discreetly so. Consider, however, different promises you might append to your expression of hope, each of which fits equally well but gives the hope expressed a different cast:

- I promise I will accept, or decline, your offer to publish without asking any other journal to expedite its review of the piece and without asking you to extend the offer deadline you provide.

- I promise I will use an offer of publication from you to seek expedited review at journals published by schools more prestigious than yours, by communicating to those journals the fact of your offer and its deadline.

These are not pleasantries. They go far beyond the calm truism, "I hope ...."

Put aside the jarring novelty of these alternatives and ask yourself two questions: First, which of the two can you see yourself including in a cover letter you write? Second, which of the two better describes what you actually do with publication offers you receive on unsolicited submissions to student-run law journals? Perhaps you can imagine making the first alternative promise. ${ }^{2}$ The opposing promise, however, seems terribly harsh. Even though it forthrightly states the way many-most?-law professors seek to trade up most of the publication offers they receive, it is difficult to imagine having the brass to say it so plainly. Just as vice cloaked in piety can hide from virtue's gaze, ${ }^{3}$ an expedited-review game can lurk behind many a simple "I hope ...."

Perhaps the typical law professor shrinks from describing the plan to ask others for expedited review because such voluble candor would be self-defeating. What law review would promptly consider a submisssion that accentuates a be-my-bargaining-chip proviso, when it could focus instead on the papers with more conventional, more congenial, cover letters? But this surmise only intensifies the realization that the common practice of requesting expedited review, parlaying publication offers from lower lows to higher highs, is morally problematic, though it involves neither force nor fraud. The fact that it is common practice-that one can find advice to junior legal scholars that

\footnotetext{
${ }^{\dagger}$ Professor, University of Georgia School of Law. (C) 2016 Joseph Scott Miller.

${ }^{1}$ Lawrence Cunningham, Sample Law Review Submission Cover Letters, Concurring Opinions, Aug 4, 2009, http://concurringopinions.com/archives/2009/08/sample-law-review-submission-cover-letters.html

${ }^{2}$ I used it, for the first time, in the cover letter that accompanied this piece.

${ }^{3}$ See François de La Rochefoucauld, Collected Maxims \& Other Reflections 63 (E.H. \& A.M. Blackmore et al. trans., 2008) (1678) ("Hypocrisy is a form of homage that vice pays to virtue.").
} 
normalizes the practice, ${ }^{4}$ and that the electronic submission platforms automate the practice $^{5}$ - does not dissolve the moral problem. Treating the authors and journals as two sides of a multi-actor matching market yields helpful insights, ${ }^{6}$ to be sure; but the market view fails to capture the fact that law professors hold positions of special trust and responsibility toward our students, and that law journals are fully integrated into a legal education that self-governing faculties must strive to provide ethically. Should we not fear to teach our students, by our example, that what matters is the height of the peak you reach, not the boot marks you leave on the bodies over which you scramble as you climb?

I have, in the past, used a law journal's offer of publication to request expedited review by one or more journals in which I would have preferred to publish. I now think I was morally wrong to have done so. I will not do it again. But why announce it? I write not to undo the wrong (I don't think I can), nor to apologize for it (though I do regret what I did). Instead, I write to explain my conclusion that requesting expedited review is immoral, in the hope it may persuade others to join me in rejecting the practice for themselves, or at the very least spark fresh discussion of its ethical status. We have moral agency here, though we seem to have lost sight of it. ${ }^{7}$ Sad to say, those who

\footnotetext{
${ }^{4}$ See, e.g., Gregory Scott Crespi, Ranking the Environmental Law, Natural Resources Law, and Land Use Planning Journals: A Survey of Expert Opinion, 23 WM. \& MARY ENVTL. L. \& POL'Y REV. 273, 286 (1998) ("Once an author receives an offer of publication, he should then first negotiate with that journal to obtain a reasonably long period of time in which to decide on that offer; ideally at least two or three weeks. The author then can commence the tiresome but necessary 'trading-up' process, whereby the author calls each of the journals to which he has submitted the manuscript that are higher-ranked than the journal that has made the initial offer and requests an 'expedited review' of the article. This study is intended to provide information useful for limiting and focusing the trading-up effort ...."). Others describe the practice without commending or condemning it. See, e.g., Nancy Levit, Scholarship Advice for New Law Professors in the Electronic Age, 16 WIDENER L.J. 947, 978-79 (2007); Shima Baradaran, Underneath the Law Review Submission Process: Part VII Expedited Reviews, PrawfsBlawg, Apr. 24, 2012, http://prawfsblawg.blogs.com/prawfsblawg/2012/04/underneath-the-law-review-submission-processpart-vii-expedited-reviews.html.

${ }^{5}$ The ExpressO platform describes its automated expedite-request system on its FAQ page for authors, http://law.bepress.com/expresso/faq_authors.html. The Scholastica platform not only automates requests for expedited review (http://blog.scholasticahq.com/post/56834643704/legal-authors-we-heardyou-introducing-more), it has published summary statistics about the practice. See Brian Cody, Law Review Article Submissions Insights: A Data-Driven Look Into the Yearly Legal Scholarship Cycle, Scholastica, 2016, http://scholasticahq.com/law-review-submissions-insights.

${ }^{6}$ Two especially insightful treatments are Paul H. Edelman, Law Clerks, Law Reviews E Some Modest Proposals, 7 GREEN BAG 2d 335 (2004), and Stephen R. Heifetz, Efficient Matching: Reforming the Market for Law Review Articles, 5 GEO. MASON L. REV. 629 (1997).

${ }^{7}$ See, e.g., Albert H. Yoon, Editorial Bias in Legal Academia, 5 J. LEGAL ANALYSIS 309, 311 (2013) ("An offer to publish does not bind the author, but rather invites the author to leverage the offer by making an 'expedite' request with a higher-ranked law journal."). Invites?
} 
think my goal is painfully old-fashioned or laughably naïve likely stopped reading at the title.

Take, as a given, that legal scholars - unlike scholars in other fields, who use a onejournal-at-a-time, peer-review model-typically submit unsolicited manuscript to multiple law reviews for their simultaneous consideration. ${ }^{8}$ For thirty years now, law professors have been shopping the publication offers they already have in hand to editors at journals they would prefer. ${ }^{9}$ Law review editors, facing a large wave of manuscripts to consider, use the expedite requests as one of their screening mechanisms. ${ }^{10}$ As information about the piece goes, the fact of an offer from another journal is probative of the piece's quality. ${ }^{11}$ Indeed, it has long been said that the most prestigious reviews rely heavily on the offers generated by other schools to focus their own efforts. $^{12}$

The immorality here is not hard to discern: The law professor who uses an offer of publication to make an expedited-review request exploits the labor the earlier-offering journal's editors put into deciding to make that offer, converting one journal's staff into an uncompensated screening staff for a different journal. The request is the very means by which the author exploits the offering journal's resources. Moreover, the professor does so for his or her own career benefit, with no reciprocal benefit to the now-rebuffed journal. ${ }^{13}$ For any given article, an author may arrogate multiple journals'

${ }^{8}$ See Levit, supra note 4, at 975-76 (describing multi-journal submission); Edelman, supra note 6, at 338 (describing the law-professor norm and contrasting it with other university disciplines).

${ }^{9}$ See Erik M. Jensen, The Law Review Manuscript Glut: The Need for Guidelines, 39 J. LEGAL Educ. 383 , 384-85 (1989) (describing the process); Jordan H. Leibman \& James P. White, How the Student-Edited Law Journals Make Their Publication Decisions, 39 J. LEgAL EdUC. 307, 409 (1989) (same).

${ }^{10}$ See Nathan H. Saunders, Student-Edited Law Reviews: Reflections and Responses of an Inmate, 49 Duke L.J. 1663, 1666 (2000) ("Finally, and most importantly, let the editors of other law journals do your work for you; that is, concentrate your effort on expedited reviews - articles which have already received an offer from another journal.").

${ }^{11} I d$. at 1666 n.12 (reasoning that an expedite request "alerts editors at the preferred law review [receiving the request] that the article is probably worth publishing (since the editorial board of a competing law review clearly believes so)").

${ }^{12}$ See Carl Tobias, Manuscript Selection Anti-Manifesto, 8o CoRNELL L. Rev. 529, 534 (1995) ("Editors of most elite reviews frequently do not read manuscripts until writers call with an offer. A number of journals ask the offeror's identity, and a few even refuse to expedite review absent that information. These editors seem content to let less prestigious journals perform initial screens, in the apparent belief that only a narrow field of high quality manuscripts will eventually float to the apex of the hierarchy."); William C. Whitford, The Need for an Exclusive Submission Policy for Law Review Articles, 1994 WIS. L. REV. 231, 231 ("Among authors it is widely believed that the 'top' reviews, such as those at Harvard or Yale, will not look at a manuscript unless the author is already famous (e.g., Richard Posner or Lawrence Tribe), or until the manuscript has been accepted at a respectable law review.").

${ }^{13}$ If the rebuffed journal is published at the author's own law school, the student editors may benefit indirectly to a small degree, if a long causal chain holds together: The author places the piece at a more 
labors, stringing a series of offers to land as desirable a placement as possible ${ }^{14}$-including, if needed, sideways moves to journals that are not more desirable but that provide a later-expiring offer, and thus supply more time in the notional trading pit. ${ }^{15}$ Finally, because this ratchet runs only one way-from less prestigious to more prestigious reviews - there is no "average reciprocity of advantage" story ${ }^{16}$ with which the editors of lower-ranked journals can console themselves. ${ }^{17}$ The work they do is redistributed up the prestige hierarchy, never to return. The authors whose works they read, and lose, freely and knowingly orchestrate that redistribution. Again, what are we teaching our students? To make sacrifices for other who need their professional help, or to sacrifice the efforts of others to their own ambitions?

The fact that the students who receive an expedite request treat it as useful information only serves to throw the immorality into sharper relief. If the student editors at Posh U Law Review take the publication offer from State U Law Review seriously, it must be that they view the State $U$ editors as having intelligence and discernment that is usefully comparable to their own. But if that is so, the author's commandeering the efforts of one to benefit the other (and himself) is all the more arbitrary and unjust; there is no substantive difference between these two sets of student editors that justifies the disparate treatment. There is, of course, a positional difference, the exploitation of which smacks of plundering oligarchs.

prestigious journal, thus bolstering the author's reputation among other legal scholars (who, it must be said, are being lazy by using the rank of the journal's publishing school as a proxy for scholarly quality). The author's school shares in that greater prestige, helping to buoy, or even enhance, the school's reputation among lawyers more generally. The school's good reputation benefits the school's alumni, including those who the author rebuffed during their time as editors at the school's law review.

${ }^{14}$ See Heifetz, supra note 6, at 635 ("[A]uthors often engage in multiple shopping expeditions. For example, an author might begin with offers from Illinois and William \& Mary, move to offers from UCLA, Wisconsin, and Texas, and ultimately accept an offer from Chicago.”).

${ }^{15}$ See Howard Wasserman, Law Reviews Playing the Game, PrawfsBlawg, March 8, 2010 (describing a law review offer designed to "keep[] authors from lateral trading just to extend the deadline and give the higher journals more time to read"), http://prawfsblawg.blogs.com/prawfsblawg/2010/o3/law-reviews-playing-the-game.html

${ }^{16}$ This construct, familiar from regulatory takings cases, and from property theory more generally, is one of "implicit in-kind compensation." Brian Angelo Lee, Average Reciprocity of Advantage, in PHILOSOPHicAl Foundations OF PROPERTy LAW 99, 100 (James Penner \& Henry E. Smith eds., 2013).

${ }^{17}$ Perhaps there is a small cohort of journals, in the upper-middle ranks, that have roughly balanced (a) outflows of offers that one group of authors uses to trade up and away, and (b) inflows of expedite requests that another group of authors uses to trade up and into their pages. But save for this cohort, we can contrast the student editors' situation with that of would-be contractors submitting detailed bid documents to fulfill an elaborate RFP, or advertising agencies or law firms making costly pitches at the behest of potential clients. For the participants in these arms-length markets, who make shot after shot over time, it is "win some, lose some." They learn, and they go again. For the less advantaged law reviews, it is "lose some, lose some," and for the most advantaged, it is "win some, win some." 
As I have reflected on the practice of requesting expedited review, coming to view it as a disgrace to the legal academy of which I am a part, I have wondered how so ostentatiously shameful practice can have persisted for so long-not only persisted, but grown and thrived. Why has the legal academy failed to come to grips with the foul careerism of the expedited-review request? Perhaps our collective failure is due, at least in part, to the fact that most law professors received their JDs from a small number of elite law schools-a plurality from Harvard, Yale, Stanford, and Chicago, with the remainder from about 20 other top-ranked schools. ${ }^{18}$ These are the very schools, the very law journals, that gain the most from the expedite-request ecosystem. Student editors at less prestigious journals suffer not only a steady diversion of labor to others' benefit, but also the demoralization of sowing again and again where they will not reap. As one student remarked, in a recent study of law review editors, "[a]uthors are brutal. They are so calculating it's scary. They would sell you into slavery if Harvard asked them to ... ." . $^{19}$ Student editors at the most prestigious journals enjoy the inflow of expedite requests, and some go on to become legal scholars themselves.

Like Professor Edelman, I think it is possible that both law review editors and legal scholars would benefit, practically, from a marked shift away from the now-standard trade-it-up, expedited-review practice. ${ }^{20}$ But that is not why I care about the now nearly universal requests for expedited review. What I find arresting about current practice is its starkly immoral character. Cognizant of my own limitations, both moral and intellectual, let me close with a humble invitation to those who reject the view that expedite requests are immoral: Please start drafting cover letters for your manuscripts that show the courage of that conviction. Proudly promise to trade up, and let us know how you fare.

${ }^{18}$ See generally Robert J. Borthwick \& Jordan R. Schau, Gatekeepers of the Profession: An Empirical Profile of the Nation's Law Professors, 25 U. MICH. J.L. REFORM 191 (1999); Donna Fossum, Law Professors: A Profile of the Teaching Branch of the Legal Profession, 5 AM. B. FOUND. RES. J. 501 (1980); Tracey E. George \& Albert H. Yoon, The Labor Market for New Law Professors, 11 J. EMPIRICAL LEGAL STUD. 1 (2014); Richard E. Redding, "Where Did You Go to Law School?" Gatekeeping for the Professoriate and Its Implications for Legal Education, 53 J. LEGAL EDUC. 594 (2003).

${ }^{19}$ Leah M. Christensen \& Julie A. Oseid, Navigating the Law Review Article Selection Process: An Empirical Study of Those With All the Power-Student Editors, 59 S.C. L. REV. 207 (2007) (ellipsis in the original).

${ }^{20}$ Edelman, supra note 6, at 341 (predicting that "[i]f the 'Just say "Yes"' norm could be inculcated in law faculty, then we might see ... faculty would apply to fewer law reviews, submitting only to those law reviews with which they have some significant likelihood of being accepted and in which they would be willing to publish. ... The law reviews would not be besieged by a flood of manuscripts that have no chance of actually appearing in the review (because they are either too awful or too good.) ... An increase in academic credibility would follow, I think, since such a process would more closely follow the traditional academic model. Perhaps law faculty would become more self-aware of the quality of their own work, since the decision of which law reviews are appropriate for submission depends on an appraisal of the quality of the article."). 